\title{
ANALISIS POTENSI PEMBANGKIT LISTRIK TENAGA MINI HIDRO DI CATCHMENT AREA WADUK JATIGEDE
}

\author{
Sinta Berliana Sipayung ${ }^{1, a)}$, Amalia Nurlatifah ${ }^{1,2, b)}$, Bambang Siswanto ${ }^{1, c)}$ \\ ${ }^{1}$ Pusat Sains dan Teknologi Atmosfer, Lembaga Penerbangan dan Antariksa Nasional (LAPAN), \\ Jl. Dr. Djunjunan No. 133, Bandung 40173 \\ ${ }^{2}$ Prodi Teknik Lingkungan, Institut Teknologi Bandung, Jl. Ganesha No. 10, Bandung 40132 \\ Email: ${ }^{\text {a)}} \underline{\text { _bbrlianasipayung@yahoo.com, }}{ }^{\text {b) }}$ amalianurlatifah92@gmail.com
}

\begin{abstract}
Abstrak
Waduk Jatigede yang merupakan waduk terbesar kedua di Asia Tenggara. Waduk akan difungsikan sebagai Pembangkit Listrik Tenaga Air (PLTA) dengan kapasitas terpasang sebesar 110 MW. Pada penelitian ini akan dilakukan prediksi potensi PLTMH di Catchment Area Waduk Jatigede sekitar DAS Cimanuk hingga tahun 2020. Data yang digunakan dalam penelitian ini meliputi data prediksi curah hujan bulanan berdasarkan keluaran model CCAM dari tahun 1998-2020. Data curah hujan akan divalidasi menggunakan data observasi curah hujan TRMM dari tahun 1998-2014. Data curah hujan keluaran CCAM digunakan sebagai data masukan estimasi debit dan tinggi muka air oleh model SWAT. Data estimasi debit dan tinggi muka air akan digunakan sebagai bahan perhitungan potensi daya. Baik hasil pemodelan CCAM, citra TRMM, CRU, maupun data stasiun menunjukan bahwa daerah catchment Waduk Jatigede (DAS Cimanuk) mempunyai pola curah hujan monsunal atau maksimum di musim DJF dan minimum di musim JJA. Data keluaran CCAM sendiri menunjukan performa yang bagus dalam mengestimasi curah hujan bulanan di daerah tersebut dibuktikan dengan tingginya korelasi antara curah hujan bulanan CCAM dan TRMM di Leuwi Daun yang mencapai sekitar 0,58 dan CCAM-Stasiun yang mencapai 0,71. Sementara di Leuwi Goong hasil korelasinya tidak jauh berbeda dan menunjukan performa yang baik pula. Menurut model ArcSWAT, terjadi penurunan debit sekitar $-2 \times 10^{-6} \mathrm{~m}^{3} / \mathrm{bulan}$ di daerah catchment area Waduk Jatigede. Penurunan tersebut dapat dibilang tidak terlalu signifikan sehingga meskipun terjadi penurunan curah hujan, namun potensi daya PLTMH di Waduk Jatigede hingga tahun 2020 adalah tetap. Potensi daya di Catchment Area Waduk Jatigede sendiri berkisar hingga 50 MW.
\end{abstract}

Kata-kata kunci: PLTMH, Curah Hujan, Debit, Daya

\begin{abstract}
Jatigede Reservoir is the second largest reservoir in Southeast Asia. The reservoir will function as a Hydro Power Plant (PLTA) with an installed capacity of 110 MW. In this research will be predicted the potential of PLTMH in Catchment Area of Jatigede Reservoir around Cimanuk Watershed until 2020. The data used in this research include monthly rainfall prediction data based on CCAM model output from 19982020. Rainfall data will be validated using TRMM rainfall observation data from 1998-2014. The CCAM output rainfall data is used as the input data of debit estimation and water level by the SWAT model. The estimated discharge data and water level will be used as a material for calculating power potential. Both CCAM modeling results, TRMM image, CRU, and station data show that the catchment area of Jatigede Reservoir (DAS Cimanuk) has a monsoonal or maximum rainfall pattern in the DJF season and a minimum in the JJA season. The CCAM output data itself shows good performance in estimating monthly rainfall in the area as evidenced by the high correlation between CCAM and TRMM monthly rainfall at Leuwi Daun which reaches about 0.58 and CCAM-Station reaches 0.71. While in Leuwi Goong the correlation results are not much different and show good performance too. According to the ArcSWAT model, there was a decrease of about $-2 \times 10-6 \mathrm{~m} 3 /$ month discharge in the catchment area of Jatigede
\end{abstract}




\begin{abstract}
Reservoir. The decline is arguably not so significant that despite the decrease in rainfall, the potential power of PLTMH in the Jatigede Reservoir by 2020 is fixed. Potential power in Catchment Area Jatigede Reservoir itself ranges up to $50 \mathrm{MW}$.
\end{abstract}

Keywords: PLTMH, rainfall, flow, power

\title{
PENDAHULUAN
}

Energi adalah hal yang dibutuhkan manusia dalam menjalankan aktivitasnya [1]. Kebanyakan orang di Indonesia bahkan di dunia saat ini menggunakan bahan bakar fosil seperti gas dan minyak bumi sebagai sumber energy utamanya [2]. Padahal kondisi bahan bakar fosil saat ini semakin menipis disebabkan bahan bakar ini tidak bisa diperbaharui dan jumlahnya semakin kecil di alam [3]. Karena krisis tersebut energi terbarukan merupakan satu-satunya solusi untuk permasalahan semakin menipisnya persediaan energi tersebut.

Waduk Jatigede merupakan waduk terbesar kedua di Asia Tenggara. Waduk ini dialiri oleh Sungai Cimanuk dalam catchment area DAS Cimanuk sebagai penyokong utama ketersediaan airnya. Besarnya aliran sungai ini diharapkan mampu menjadi solusi bagi permasalahan krisis energi di dunia khususnya di wilayah sekitar Jatigede dengan dibangunnya Pembangkit Listrik Tenaga Minihidro di sekitar aliran Sungai Cimanuk.

Waduk Jatigede berada di Daerah Aliran Sungai (DAS) Cimanuk mulai digunakan untuk mengairi areal pesawahan di daerah pantai utara (pantura), seperti Majalengka, Indramayu dan Cirebon. Waduk Jatigede (Sumedang) dianggap mampu menyuplai air kedaerah pantura dalam beberapa tahun kedepan dan mampu mengairi Daerah Irigasi Rentang seluas 90.000 ha, seperti mengairi sawah di Kab.Indramayu, Cirebon, Majalengka dan sekitarnya, dan akan difungsikan sebagai Pembangkit Listrik Tenaga Air (PLTA) dengan kapasitas terpasang sebesar $110 \mathrm{MW}$ yang dapat menghasilkan Pembangkit Listrik Tenaga Air dengan install capacity sekitar 110 MW dan akan dikelola oleh Perusahaan Litrik Negara (PLN) [4].

Penelitian ini bertujuan menghitung potensi besarnya daya yang dapat dibangun di Pembangkit Listrik Tenaga Minihidro di sekitar aliran Sungai Cimanuk yang bermuara ke Waduk Jatigede.

\section{METODE PENELITIAN}

Dalam penelitian ini, dibangun prediksi curah hujan yang nantinya akan dijadikan data masukan untuk pemodelan debit di DAS Cimanuk Hulu (Leuwi Daun, Leuwi Goong, dan Pamegatan) sehingga dari besaran debit tersebut dapat dihitung potensi daya yang dapat terjadi di PLTMH yang dapat dibangun di daerah aliran sungai sekitar Sungai Cimanuk dan Waduk Jatigede. Secara singkat, diagram alir penelitian dapat dilihat pada gambar 1. 


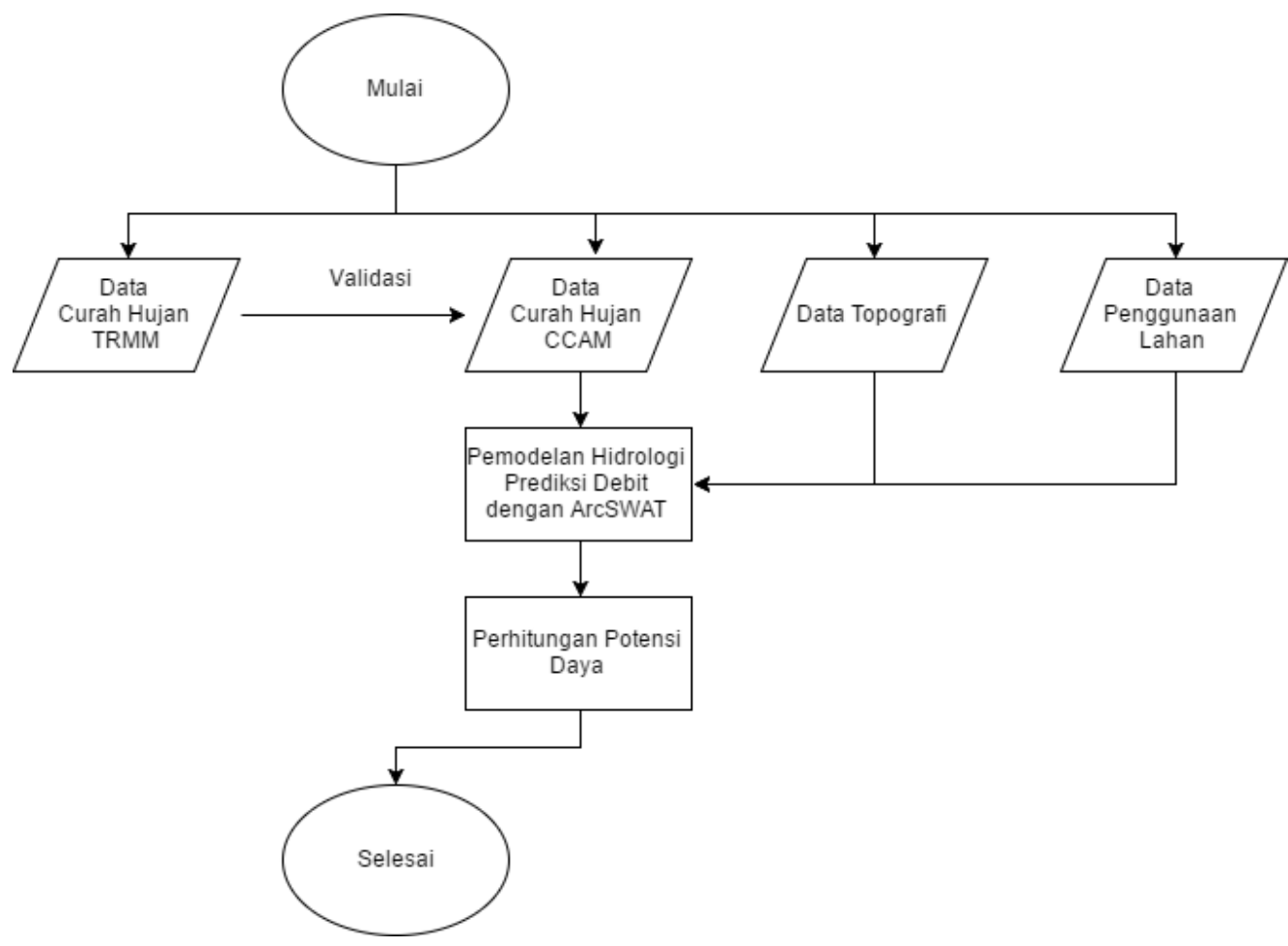

GAMBAR 1. Diagram alir penelitian

\section{Data}

Data Satelit

Data curah hujan dari TRMM digunakan sebagai validasi model CCAM. Data TRMM yang digunakan adalah data curah hujan dari tahun 2006-2014.

\section{Data Masukan ArcSWAT}

ArcSWAT merupakan model integrasi ArcGIS dan SWAT yang dapat digunakan dalam analisis pemodelan hidrologi seperti debit [5]. Model ini memerlukan 3 jenis data masukan yaitu data iklim, data penggunaan lahan, dan data topografi.

1. Data Iklim (keluaran CCAM)

Data iklim yang digunakan sebagai masukan untuk model ArcSWAT adalah data hasil keluaran model CCAM dari tahun 2006-2020.

2. Data Penggunaan Lahan

Data penggunaan lahan didapat dari Balai Besar Wilayah Sungai (BBWS) CimanukCisanggarung.

3. Data Topografi

Data DEM SRTM merupakan data topografi didapat dari CGIAR-CSI berupa data elevasi SRTM (Shuttle Radar Topography Mission) dan dapat diakses di alamat URL http://srtm.csi.cgiar.org/.

\section{Metode Perhitungan Daya}

Pembangkit tenaga air adalah suatu bentuk perubahan tenaga dari tenaga air dengan ketinggian dan debit tertentu menjadi tenaga listrik, dengan menggunakan turbin air dan generator [6]. Potensi daya dihitung berdasarkan formula berikut [7].

\section{$P=9,81 \times Q \times H \_$eff}

Dimana:

$\mathrm{P}$ : potensi daya secara teoritis (watt)

$\mathrm{Q}:$ debit $\left(\mathrm{m}^{3} / \mathrm{det}\right)$

H_eff : tinggi jatuh efektif (m) 
Dalam penelitian ini akan dihitung potensi daya yang dapat dihasilkan dari PLTMH ini sebagai fungsi dari debit. Oleh karena itu, diambil suatu asumsi dimana efisiensi generator, daya jatuh efektif, dan efisiensi turbin adalah tidak berubah dan sama seiring berjalannya waktu. Pada penelitian ini diambil tinggi jatuh efektif sebesar 20 meter dimana kategori ini termasuk kategori rendah menuju tinggi (sedang) [8].

\section{ANALISIS DAN PEMBAHASAN}

Salah satu keuntungan pemakaian energi minihidro adalah untuk menghasilkan energi ini tidak diperlukan banyak persyaratan besar seperti tersedianya waduk [9]. Sungai pun dapat dijadikan sebagai sumber penggerak turbin untuk energi minihidro.

Daerah DAS Cimanuk Hulu terlihat bahwa daerah dengan Topografi tinggi berada di batas-batas DAS Cimanuk Hulu bagian selatan (Gambar 2).

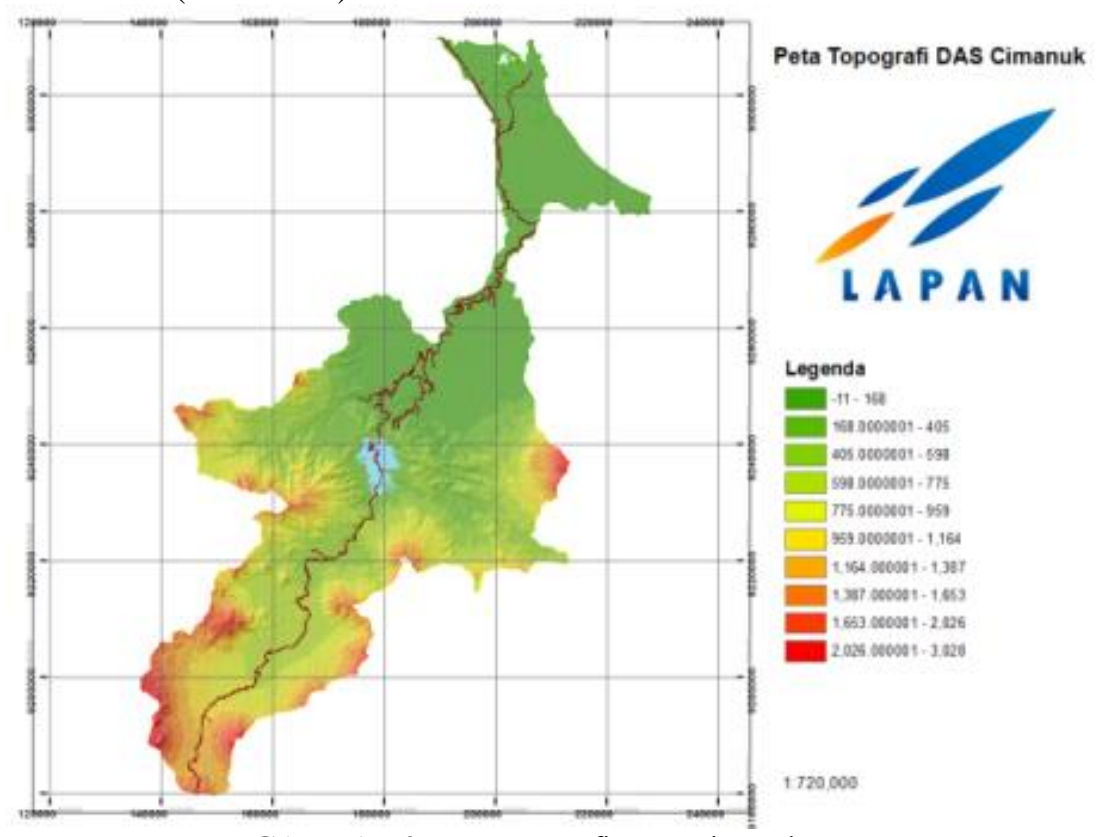

GAMBAR 2. Peta topografi DAS Cimanuk

Daerah ini dibatasi oleh Gunung Cikuray dan Gunung Papandayan. Pada penelitian kali ini dipilih 3 titik yang akan dihitung potensi debitnya yaitu di Leuwi Daun, Leuwi Goong, dan Pamegatan (Gambar $3)$. 


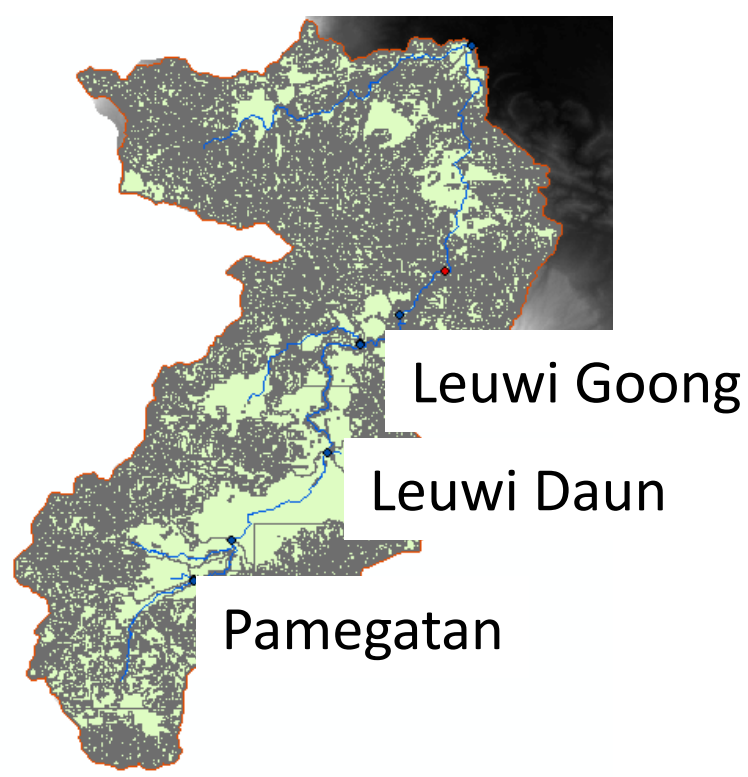

GAMBAR 3. Letak lokasi penelitian

Sementara curah hujan di Leuwi Goong dan Leuwi Daun sendiri cenderung mempunyai pola curah hujan monsunal dengan puncak curah hujan tertinggi berada di bulan Januari dan Desember. Curah hujan terendah cenderung terjadi di bulan Juni-Agustus (gambar 4a dan 4b). Hal ini memicu sebuah prakiraan bahwa debit Sungai Cimanuk di Leuwi Goong dan Leuwi Daun akan mencapai maksimum di Bulan Desember-Januari dan mencapai minimum di Bulan Juni-Agustus. Ini menyebabkan potensi debit PLTMH di Leuwi Goong dan Leuwi Daun akan mencapai maksimum di Bulan Desember-Januari dan mencapai minimum di Bulan Juni-Agustus.

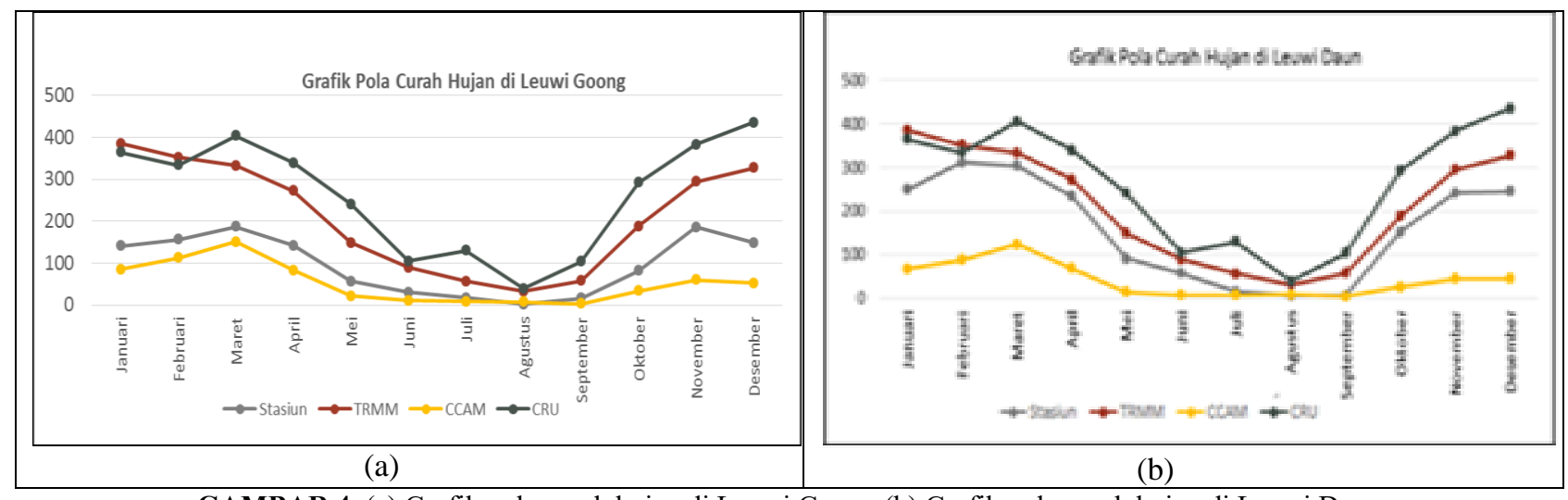

GAMBAR 4. (a) Grafik pola curah hujan di Leuwi Goong (b) Grafik pola curah hujan di Leuwi Daun

Data curah hujan CCAM yang digunakan sebagai data input pemodelan hidrologi untuk menghitung debit sendiri diketahui mempunyai validitas yang baik sehingga dapat digunakan sebagai bahan analisis dan prediksi kondisi debit di Sungai Cimanuk. Data CCAM mempunyai korelasi sebesar 0,58 dan 0,71 di Leuwi Daun masing-masing dibandingkan terhadap data TRMM dan data stasiun. Sementara data CCAM di Leuwi Goong mempunyai korelasi 0,62 dan 0,57 masing-masing dibandingkan dengan data TRMM dan data stasiun.

Berdasarkan hasil pemodelan ArcSWAT dapat dilihat bahwa baik di Leuwi Daun, Leuwi Goong, maupun Pamegatan cenderung menurun meskipun penurunannya hanya sedikit saja dan cenderung tetap (nilai koefisien x negatif dan mendekati 0) (Gambar 5). Hal ini menunjukan bahwa debit bulanan di Sungai Cimanuk hingga tahun 2020 diprediksi akan tetap sama (penurunannya hanya sedikit saja). Hal ini membuat sebuah dugaan bahwa daya PLTMH di Sungai Cimanuk akan tetap sama potensinya hingga tahun 2020. 
Sementara rata-rata debit tertinggi berada di Leuwi Goong dengan besaran debit maksimum dapat mencapai 250 m3/detik, lalu di Leuwi Daun berkisar 100-150 m3/detik, dan di Pamegatan sekitar 50-100 m3/detik. Hal ini membuat sebuah prediksi pula bahwa potensi daya di Sungai Leuwi Goong paling tinggi jika dibandingkan di Sungai Cimanuk di titik yang lain (Leuwi Daun dan Pamegatan) (Gambar 5).

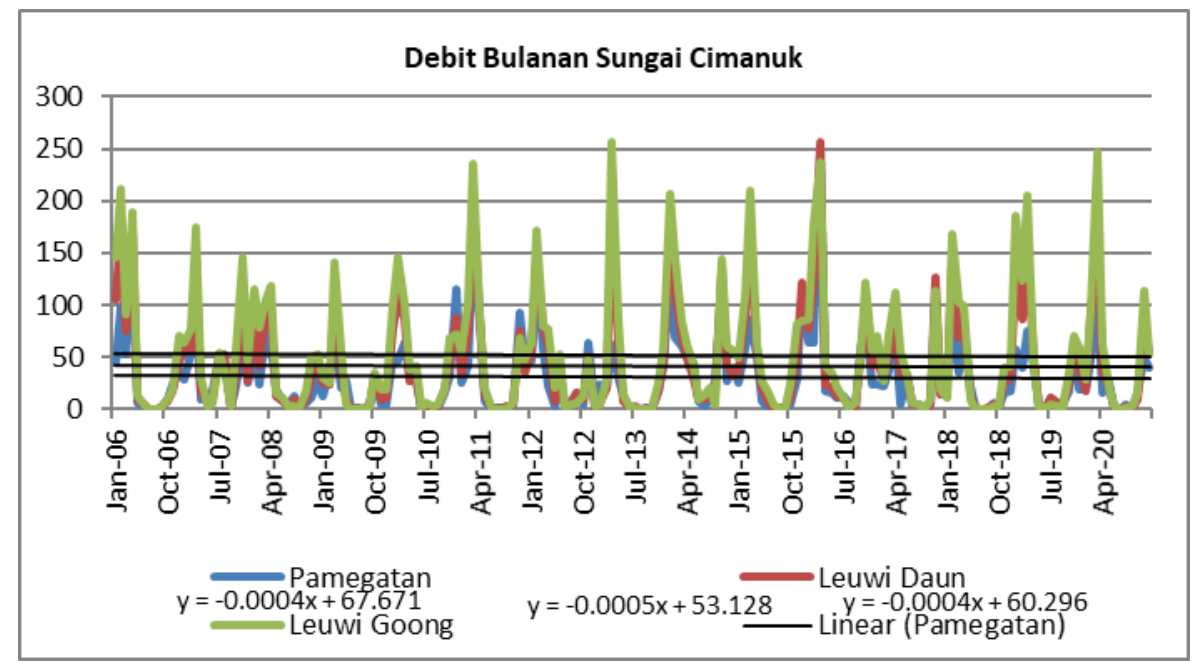

GAMBAR 5. Debit bulanan Sungai Cimanuk

Perlu digarisbawahi bahwa dalam penelitian ini, hanya akan dilihat tren penurunan ataupun kenaikan potensi PLTMH di DAS Cimanuk berdasarkan tinjauan kondisi cuaca akibat perubahan iklim saja. Dengan demikian, dalam penelitian ini diasumsikan tinggi jatuh efektif yang digunakan adalah sekitar 20 meter dan ketinggian ini dianggap tetap hingga tahun 2020. Artinya, hingga tahun 2020 dianggap tidak terjadi perubahan tata guna lahan ataupun perubahan topografi di sekitar DAS Cimanuk.

Dalam perancangan energi mini hidro sendiri terdapat banyak hal yang dapat mempengaruhi performanya termasuk dengan kondisi turbin [10]. Energi mini hidro sendiri dipandang sebagai salah satu solusi terhadap permasalahan ketersediaan energi karena sifatnya yang merupakan energi terbarukan dan minim emisi GRK sehingga kecil dampaknya terhadap perubahan iklim. Namun kelemahan dari PLTMH ini adalah terdapat efek negatif secara lokal terutama pada ekosistem sungai dan riparian, artinya PLTMH terkadang dianggap dapat mengurangi keanekaragaman hayati perairan dan mengurangi komunitas riparian [11].

Dengan menggunakan asumsi-asumsi diatas, dapat dilihat bahwa potensi daya di sekitar Sungai Cimanuk terlihat cukup besar. Nilainya berkisar hingga $50 \mathrm{MW}$ di Leuwi Goong, Leuwi Daun, maupun Pamegatan. Namun rata-rata potensi daya di Leuwi Goong merupakan yang paling besar diantara ketiganya dengan potensi daya sekitar $10 \mathrm{MW}$, di Leuwi Daun potensinya mencapai $8 \mathrm{MW}$, dan $6 \mathrm{MW}$ di Pamegatan (Gambar 6).

Jika dilihat dari hasil regresi linier terhadap kondisi debit di Gambar 5, maka dapat kita lihat bahwa koefisien slope $\mathrm{x}$ dari masing-masing debit di Leuwi Daun, Leuwi Goong, maupun Pamegatan bernilai kecil namun negatif. Jika dilihat dari nilai potensi daya PLTMH pun nilai rata-ratanya pertahun cenderung sama hingga tahun 2020. Oleh karena itu dapat disimpulkan bahwa dari segi faktor cuaca dan debit, potensi daya PLTMH di DAS Cimanuk hingga tahun 2020 adalah tetap (hanya menurun sedikit). 


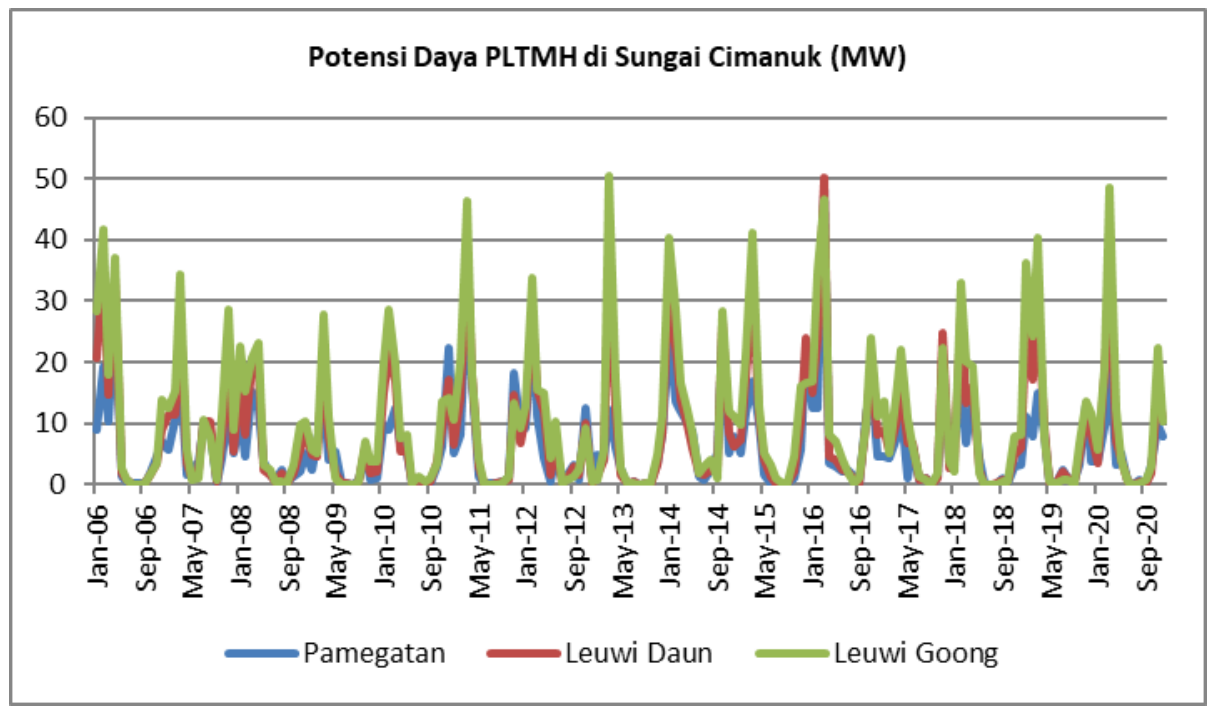

GAMBAR 6. Potensi Daya PLTMH di Sungai Cimanuk (dalam MW)

\section{SIMPULAN}

Curah hujan di DAS Cimanuk bertype monsunal yang artinya curah hujan akan tinggi pada musim DJF (Desember-Januari-Februari) dan akan rendah pada musim JJA (Juni-Juli-Agustus). Hal ini menimbulkan debit Sungai Cimanuk akan maksimal pada musim DJF dan minimal pada musim JJA. Hasil pemodelan CCAM terhadap curah hujan mempunyai korelasi yang baik jika dibandingkan dengan data TRMM maupun Stasiun. Di Leuwi Daun, korelasinya mencapai 0,58 terhadap TRMM dan 0,71 terhadap stasiun. Di Leuwi Goong, korelasinya mencapai 0,62 terhadap TRMM dan 0,57 terhadap data stasiun.

Berdasarkan analisis terhadap kondisi debit yang akan berpengaruh terhadap potensi daya di DAS Cimanuk, dapat disimpulkan bahwa daya PLTMH di DAS Cimanuk yang bermuara ke Waduk Jatigede adalah tetap hingga tahun 2020. Analisis regresi linier menyebutkan terjadi penurunan perbulannya namun penurunan tersebut hanya sedikit sekali dengan nilai slope hampir mencapai 0 . Nilai tersebut artinya ratarata debitnya akan selalu sama hingga tahun 2020.

Proyeksi potensi PLTMH di Sungai Cimanuk menyebutkan bahwa terdapat potensi daya hingga 50 MW di sungai ini. Jika dilihat dari kondisi regresi linier debitnya, maka potensi daya ini juga akan tetap hingga tahun 2020.

\section{UCAPAN TERIMAKASIH}

Penulis mengucapkan terimakasih kepada Pusat Sains dan Teknologi Atmosfer, LAPAN atas dukungan dana sehingga penelitian ini dapat terselenggara pada program tahun anggaran 2016.

\section{REFERENSI}

[1] FAO. 2001. Human energy requirements.

[2] Astra, I. 2010. Energi dan Dampaknya Terhadap Lingkungan.

[3] Manieniyan, V. dan M Thambidurai. 2009. Study on Energy Crisis and The Future of Fossil Fuels.

[4] Sumedangonline.com

[5] Anlauf, Ruediger. 2008. Watershed Modeling with ArcSWAT: Calibration and Validation for the Prediction of Flow, Nitrate and Phosphorus load. International Meeting on Soil Fertility Land Management and Agroclimatology. Turkey, 2008. p:279-288 
[6] Warsito S, 2005, Studi Awal Perencanaan sistem Mekanikal dan Kelistrikan Pembangkit Listrik Tenaga Mini-Hidro, Seminar Nasional Teknik Ketenagalistrikan, UNDIP.

[7] Niemann, G. dan H. Winter. 1992. Elemen Mesin. Jakarta: Erlangga

[8] Firmansyah, R., Teguh Utomo, Hery Purnomo. 2014. Perancangan Pembangkit Listrik Tenaga Mikrohidro Gunung Sawur unit 3 Lumajang.

[9] Nasir, B. 2003. Design of Micro - Hydro - Electric Power Station.

[10] Ahmad, A., Amin, A., Akhtar H., Talib F. 2016. Efficiency Improvement of Mini Hydro Pump Storage Power Plant Using Archimedes Turbine.

[11] Silva, E.I.L., E.N.S. Silva. 2016. Mini-Hydro, an Injurious Novel Threat to Highland Forest Ecosystems of Sri Lanka 